\title{
Quando o teatro tece a trama - Apontamentos históricos na dramaturgia de Jorge Andrade
}

Luiz Humberto Martins Arantes

Doutorando - PUC-SP / FAPESP

\section{RESUMO}

Este artigo discute, a partir da relação história e teatro, o lugar do dramaturgo paulista Jorge Andrade (1922-1984) no centro do teatro brasileiro. Para isso, toma-se como ponto de partida a peça A Moratória, escrita em 1954, que é considerada uma das principais obras do autor e apresenta aspectos da decadência das elites cafeeiras em torno de 1930. Produzida e encenada nos anos 50, trata-se de um importante documento sobre a necessidade de se representar o "homem brasileiro" naquele contexto.

Palavras-chave: teatro; Jorge Andrade; nacionalismo.

\section{ABSTRACT}

This paper discusses, from the relation between history and drama, the place of the São Paulo-born dramatist Jorge Andrade $(1922$ - 1984) at the heart of the Brazilian theatre. To do so one takes as starting point the play A Moratória, written in 1954, which is considered one of the author's main works and presents some features of the coffee elite decadence round 1930. This play was written and performed in the 50's and it came to be an important record on the need of standing for the Brazilian man in that time.

Keywords: drama; Jorge Andrade; nationalism.

Atualmente, muitos cruzamentos entre literatura e história vêm sendo realizados. As fronteiras de uma e outra são estreitadas em alguns momentos e reafirmadas em outros. Se há uma aproximação possível, pode-se iniciá-la com o fato de ambas lidarem com a passeidade.

Em termos numéricos, a abordagem de historiadores acerca de dramaturgos e textos teatrais é bem menor. Talvez pelo próprio fato de a crítica literária, em alguns momentos, não considerar textos teatrais como sendo literatura. Depois, também pela dúvida dos historiadores em tomar o literário como documento de pesquisa histórica ${ }^{1}$. No presente texto, o dramaturgo Jorge Andrade e sua peça A Moratória serão estudados com o objetivo de se perceber a representação de brasilidade que tal peça torna possível no decorrer da década de 50 .

0 dramaturgo Jorge Andrade ${ }^{2}$ formou-se e passou a pensar em teatro a par- 
tir de duas importantes casas de teatro: TBC (Teatro Brasileiro de Comédia) e EAD (Escola de Arte Dramática). Historicamente, pode-se dizer que elas caminharam paralelas. A fundação da EAD, em 1948, por Alfredo Mesquita, concretizou a intenção de uma escola de formação de atores que fizesse eco à reformulação do sistema educacional brasileiro iniciado em 1930, pois, desde então, novas carreiras passaram a ser valorizadas e mais profissionais são requisitados por uma vida urbana e frenética.

0 início do TBC, em 1948, possibilitou a emergência do teatro paulistano em bases empresariais. Se, por uma perspectiva, boa parte do repertório era estrangeiro, por outra, é inegável que o TBC torna-se, no início da década, um centro de recepção de atores formados na EAD (Escola de Arte Dramática). 0 TBC surge, assim, como centro divulgador da necessidade do ator nacional. ${ }^{3}$

No Brasil, o advento desse teatro postulado pelo grupo de Mesquita significou a negação de outras formas de representação. Em outras palavras, acreditou-se ser necessário mudar o esquema de produção, cujo modelo se apoiava nas vedetes e no ator único. Os principais alvos dessa insatisfação foram as companhias de Procópio Ferreira e Jaime Costa.

$\mathrm{Na} \mathrm{EAD}$, escola que formou Jorge Andrade, para além da idéia de profissionalização e de assentamento do teatro em bases empresariais, estava em pauta o desejo de distanciar o teatro de suas cores mais populares e cotidianas, como o teatro de revista e outras formas "amadoras" de produção.

Nas origens da EAD, a necessidade de formar um ator nacional vem, pois, acompanhada da idéia de rigor profissional, valorização do texto e centralização do processo criador em torno de um dramaturgo e depois de um diretor.

Em depoimentos, Alfredo Mesquita sempre lembra o arrojado empreendimento de seu grupo. Em comentário sobre o empresário Franco Zampari, empresário ligado ao TBC e à Vera Cruz, Alfredo Mesquita parece falar de si mesmo:

Ele, a despeito de sua imensa fortuna, não tinha o menor interesse pela bilheteria, somente o nível artístico dos espetáculos empolgava a ele. Seu maior sonho era reunir todo o teatro nacional em um grande truste controlado por ele, com dezenas de elencos atuando simultaneamente em São Paulo, no interior paulista, no Rio de Janeiro e em todo o Brasil. ${ }^{4}$

Como se percebe, a estrutura empresarial que ligava EAD, TBC e Vera Cruz nem sempre é assumida como tal pelos organizadores. Movidos por uma vontade de construção da cultura nacional, ressaltam o fato de terem feito tudo isso sem maiores motivações financeiras. Assim, de maneira alguma a idéia de formação de mercado interno de produtos culturais é reconhecida. 
Jorge Andrade ingressou na EAD em 1951. Mais que aluno, estabeleceu relações e afinidades com o grupo de Mesquita e Décio de Almeida Prado, encontrando nestas figuras as referências intelectuais de que necessitava.

Ao longo de sua formação, irá apreender toda uma peculiar maneira de observar a realidade brasileira. Irá incorporar, na EAD, a necessidade de se formar uma certa consciência nacional. Ao buscar no passado as raízes do homem brasileiro, constitui-se como divulgador desse "projeto" de formação do ator nacional e também do dramaturgo com "cores locais". Foi ancorando-se nas referências que a sua formação lhe forneceu que o dramaturgo entendeu que seria urgente teatralizar a rápida trajetória que ele e seu país estavam, naquelas últimas décadas, realizando, ao optarem pela cidade como espaço de construção de riquezas e valores.

Se a EAD representou a casa da educação e formação de atores e dramaturgos, tornando-os intérpretes da consciência nacional, corria, paralela, a ação do $\mathrm{TBC}$, cabendo-lhe a tarefa de levar à cena, de realizar o encontro entre ator, texto e diretores. Sobre os resultados daí advindos, foi Mesquita quem pontuou que: (...) dou a maior importância ao teatro amador como formador do verdadeiro teatro nacional, sobretudo ao TBC, que em meses conseguiu transformar esse teatro mambembe em cultura e seriedade. ${ }^{5}$

No que tange ao trabalho dos atores do TBC, pode-se dizer que as experiências de inúmeras montagens a cada ano - exigências de bilheteria — possibilitaram-lhes um considerável depuramento técnico, proporcionando uma nítida ruptura com a interpretação até então em voga, isto é, a de Procópio Ferreira e Jayme Costa. Assim, ao contrário das tradicionais companhias, inúmeras montagens do TBC passaram a exigir elencos maiores e a descentralização do ator "vedete". 6

Tal como no teatro mundial do pós-guerra, também no TBC prevaleceram as variações em torno da estética realista. Havia, pois, uma clara aposta em textos que aproximavam palco e cotidiano. Textos que dialogavam com uma cidade de São Paulo, que crescia aceleradamente, e que, ao mesmo tempo, observava a expansão de um público disposto a freqüentar salas de teatros.

Se estas efervescentes movimentações no meio artístico/empresarial de São Paulo foram pontuais na formação de Jorge Andrade, não deixaram também de o ser as referências estrangeiras e nacionais sobre escrita teatral.

Jorge Andrade nunca omitiu opiniões a respeito das obras que considerava fundamentais para a composição de seus textos teatrais. Compreender seu projeto de escrita teatral requer observar também as peculiaridades das dramaturgias com as quais dialogou. Para tratar do tema ruralidade, o autor teve que estabelecer contatos com referências da dramaturgia estrangeira e com o teatro brasileiro de seu tempo. 
Em entrevistas, o dramaturgo Jorge Andrade nunca deixou de mencionar suas referências acerca do que ele chama de dramaturgia de 'qualidade'. 0 russo Anton Tchekov é sempre lembrado por seus textos, em que privilegia a decadência da sociedade "aristocrática" russa, em fins do século XIX.

A partir dessa referência, Jorge Andrade recriou não só a temática "alteração de um modo de vida rural”, mas tomou-a também como uma opção estética e política. Em outras palavras, a proximidade com a dramaturgia tchecoviana significou marcar posição diante do teatro no Brasil dos anos 50 e 60. Esta possibilidade aparece nas próprias palavras do dramaturgo: Veja o Tchekov. Seu teatro é político, pois marca toda a morte de uma sociedade, anunciando uma era que vai começar. É o grande dramaturgo pré-revolucionário da Rússia. Preferem o Gorki, que foi do partido.

Ainda sobre as leituras que definem a formação de Jorge Andrade e deixam rastros em suas obras, é preciso não se esquecer do americano Arthur Miller e de seus pressupostos acerca do realismo psicológico.

A aproximação com o teatro norte-americano pode ser estudada por vários caminhos. Dentre eles, lembrar-se de que o pós-Segunda Guerra Mundial sintetiza o momento de consolidação dos norte-americanos como potência econômica, política e cultural. Portanto, momento em que a situação econômica e financeira do Brasil caminha no sentido de acentuar a dependência em relação aos Estados Unidos ${ }^{8}$.

A encenação de A morte do caixeiro viajante de Artur Miller, em 1951, tendo à frente $o$ ator Jayme Costa, foi para o dramaturgo Jorge Andrade, naquele momento, em seu primeiro ano de curso de teatro, um dos primeiros contatos com a dramaturgia norte-americana.

Semelhante ao que ocorre em A Moratória e O Telescópio, no texto de Miller, o leitor/espectador acompanha, na esfera dos personagens, o impacto que a crise econômica pós-1930 impõe à sociedade norte-americana.

Nos Estados Unidos, o "realismo psicológico" teve em Arthur Miller e Tennessee Williams importantes expoentes e divulgadores. Miller, em rápido encontro com o dramaturgo Jorge Andrade, incentivou-o a escrever sobre seu povo, suas diferenças e expectativas.

Em território norte-americano, os autores do realismo psicológico possuíam um específico lugar. Como intelectuais próximos de segmentos de esquerda, propuseram textos teatrais que debateram os impactos da crise econômica pós1930 na sociedade americana. Como bem lembra Maria Silvia Betti:

(...) ao sabor das drásticas rupturas impostas pelo projeto de industrialização e modernização urbanizadora, temáticas como a da inadequação entre passado e presente, eixo central do trabalho de Williams, e a da patética solidão do indiví- 
duo ilhado em seu fracasso, tema recorrente em Miller, tornam-se incrivelmente próximas e tocantes. ${ }^{9}$

Em Jorge Andrade, todos esses princípios do realismo psicológico (Biff/ Willy Loman) - patética solidão do indivíduo ilhado em seu fracasso - serão organizados para pensar no impacto da crise de 1930 na esfera dos personagens (Marcelo/Joaquim). Diferentemente na realidade brasileira, as rupturas oriundas das transformações eram decorrentes da desestruturação de um sistema produtor calcado na propriedade agrícola monocultora. É, portanto, a carpintaria teatral do realismo psicológico amalgamando-se ao tema da decadência rural. Em outras palavras, a serviço de uma memória individual que, ficcionalmente, refaz a trajetória do rural ao urbano.

Se a dramaturgia tchecoviana e o realismo psicológico forneceram matériaprima formal para a composição dos textos andradinos, a mesma proximidade pode ser percebida com a dramaturgia nacional. Mesmo tendo estreado sua primeira peça - A Moratória, no Teatro Maria Della Costa, em 1955 - fora dos palcos do TBC (Teatro Brasileiro de Comédia), isto não significa dizer que Jorge Andrade não possuía ligações e algumas diferenças com as opções estéticas dos proprietários e dramaturgos daquela casa.

Ligações porque a encenação de A Moratória simbolizou a apropriação de temáticas que, no TBC, estavam atraindo público. Tensões, porque a criação de outras companhias profissionais em São Paulo começava a incomodar as pretensões dos empresários do TBC.

Assim, a incorporação formal do realismo psicológico e da temática "famílias rurais em decadência", no conteúdo está, nos anos 50, pulsando no meio teatral paulista, e atende ainda a uma necessidade de consumo de segmentos da população.

No que diz respeito ao tema "segmentos sociais em desagregação", o teatro paulista da década de 50 forneceu vários dramaturgos, dentre eles: Abílio Pereira de Almeida, Clô Prado e Edgar da Rocha Miranda.

0 mais produtivo deles foi, sem dúvida, Abílio Pereira de Almeida, um dos fundadores do TBC que, a partir de 1951, mergulharia fundo nos projetos da Companhia Cinematográfica Vera Cruz, em que trabalhou para a produção de filmes como Caiçara e Terra é Sempre Terra.

Desde então começou a se impor também como roteirista e dramaturgo. Dentre seus textos teatrais, a crítica costuma valorizar as peças Paiol Velho e Santa Marta Fabril S/A. Segundo Alberto Guzik, a dramaturgia de Abílio possui altos e baixos:

As personagens são bem desenhadas, o diálogo flui com grande espontaneidade 
na maior parte das cenas e 0 autor insufla na obra um clima de decadência que se impõe sem que pareça falseado ou ilógico. 0 que a peça tem de menos satisfatório são a tendência ao melodrama e à trama, que chega a beirar o simplismo. Tratando da decadência rural e da ascensão de outra classe social sem títulos e nomes ilustres, que a substitui na posse da terra, 0 autor não foge a velhos estereótipos. ${ }^{10}$

Neste contexto, aparece ainda o nome de Clô Prado. Autora que, mais uma vez, retoma a temática familiar. Sua peça "Diálogo de surdos" é centrada num conflito familiar situado na alta burguesia e nela aparece uma cuidadosa construção de enredo.

Um dramaturgo também preocupado com famílias e com o universo rural é Edgar da Rocha Miranda. A encenação, em 1952, de Para Onde a Terra Cresce, foi para o TBC um fracasso de bilheteria, mas que, mesmo assim, em 1954, aceitaria um novo texto do autor: E o noroeste soprou. Classificado também como um drama rural.Esse ciclo de peças rurais no TBC tem o seu auge, e provavelmente seu desfecho, com outra peça de Abílio Pereira de Almeida: Santa Marta Fabril S.A. Neste texto, mais uma vez o diálogo com o passado - 1932 - e com as famílias paulistanas "quatrocentonas" está de volta. Pela crítica de Miroel Silveira, é possível acompanhar o impacto do texto e a importância de peças com tal conteúdo naquele momento dos anos 50 . Afirma o crítico:

Para quem encara a peça de Abílio Pereira de Almeida de um ponto de vista socialista, é animador verificar que os próprios elementos da aristocracia, como o autor, timbram em revelar de público as mazelas de uma classe dirigente, fazendolhe um auto-de-fé espetacular. Para os amigos e membros do clã social a que pertence 0 autor, deverá ser incômodo verificar que abrigaram em seu seio a própria onça, pois de tantas figuras que passam pela peça, vivida num ambiente de paulistas de 400 anos, ele não salvou nenhuma que fosse decente ou digna. ${ }^{11}$

0 esquema tebeciano de montagens de peças teatrais com as temáticas acima apontadas parece ter transposto barreiras. Escrevendo para teatro desde 1951, o dramaturgo Jorge Andrade teve a sua estréia em 1955, com o texto A Moratória.

Tendo estudado e se formado próximo aos expoentes da dramaturgia brasileira acima elencados, Jorge Andrade se apresentará como sendo o desdobramento e o refinamento das intenções dessas referências.

Ao passar por uma escola de arte, Jorge Andrade forma-se técnica (dramaturgo/ator) e intelectualmente para a escrita teatral. Ao escrever seus textos, publicá-los, encená-los e receber premiação por alguns, expõe-se como homem 
público. Assim, insere-se com suas obras em importantes debates com a intelectualidade e com o campo político nos anos 50 .

A idéia de se refletir teatralmente o homem brasileiro a partir das transformações ocorridas no espaço - rural e urbano - e no tempo - passado e presente - é um projeto muito evidente na dramaturgia de Jorge Andrade.

Num ambiente onde tudo está em formação, não devemos nos esquecer dos valores, ou melhor, dos exemplos que o passado encerra. Para escolher o caminho justo, ou saber distinguir os valores que devemos levar em conta, para a formação de um futuro que justifique tanto os esforços como os resultados alcançados, não podemos esquecer as grandes verdades encerradas neste passado; são elas que esclarecem o presente e o justificam. Por que esquecer o que temos, esquecer nosso passado, nossa realidade, e pensar somente em realidades ou verdades que não nos dizem respeito? Por que continuar, eternamente, nesta imitação barata de formas que não nos pertencem? Nunca tive nem tenho a pretensão de inovações. Desejo apenas guiar-me, sinceramente, pelos exemplos e lições que a realidade brasileira a cada passo nos apresenta. Através do teatro procuro um meio de expressão e tento exprimir meu próprio meio — nada mais. (...) [Em] A Moratória e $O \mathrm{Te}$ lescópio procurei apresentar um quadro sincero e verídico da decadência dessas famílias [aristocráticas], depois da crise de 1929 e da revolução de 1930. Acho que o teatro brasileiro não necessita nada mais do que de sinceridade, sinceridade de cada um nos seus propósitos. É o que, como muitos, tenho tentado ter. ${ }^{12}$

É perceptível a preocupação com o tempo, muito mais com o passado, mas esta, sempre como resposta a um presente e também como idealização de um futuro a ser construído. Para Jorge Andrade, olhar o passado equivale a tecer a história, voltar-se às suas próprias raízes, às origens do homem brasileiro.

$\mathrm{Na}$ historiografia brasileira, tal pensamento é muito marcante nas obras de Sérgio Buarque de Holanda, que fora, na juventude, uma leitura imprescindível de Andrade. Para o historiador, a busca das origens do brasileiro deve estar amarrada à questão de sua ruralidade. Daí, mencionar que (...) não foi a rigor uma civilização agrícola o que os portugueses instauraram no Brasil, foi, sem dúvida, uma civilização de raízes rurais. ${ }^{13}$

Há, segundo o historiador, uma forte herança rural proveniente dos tempos coloniais e que, desde então, estabelecera a distinção entre o que é urbano e o que pertence ao rural, recuperando, desse modo, a clássica distinção, de origem européia, entre a cidade e a aldeia.

Em termos políticos, Sérgio Buarque já menciona a existência de uma situação de dependência da cidade mediante o poder dos meios rurais. Haveria então, desde nossa colonização, uma crença (...) em certa misteriosa "força cen- 
trífuga" própria ao meio americano e que tivesse compelido nossa aristocracia rural a abandonar a cidade pelo isolamento dos engenhos e pela vida rústica das terras de criação. ${ }^{14}$

No texto teatral A Moratória, aqui escolhido para acompanhar como essa passagem rural/urbano se dá na dramaturgia brasileira, o dramaturgo Jorge Andrade lança também preocupações com a questão rural/urbano no Brasil, porém, olhando outro contexto: o Brasil pós-1929.

Escrita em 1954, A Moratória reforçará a idéia de que houve uma passagem do rural para o urbano no seio da sociedade brasileira pós-30, pois o dramaturgo traz para o texto personagens que habitam ora uma fazenda, ora uma pequena cidade. Este contraste aparece logo de início na rubrica de cenário:

Dois planos dividem o palco mais ou menos em diagonal. Primeiro plano ou plano da direita: sala modestamente mobiliada. Na parede lateral direita, duas portas: a do fundo, quarto de Marcelo; a do primeiro plano, cozinha. Ao fundo da sala, corredor que liga às outras dependências da casa. À esquerda, mesa comprida de refeições e de costura; junto a ela, em primeiro plano, máquina de costura. Encostado à parede lateral direita, entre duas portas, banco comprido, sem pintura. Na mesma parede, bem em cima do banco, dois quadros: coração de Jesus e Coração de Maria. Acima dos quadros, relógio grande de parede. No corte da parede imaginária que divide os dois planos, preso à parede como se fosse um enfeite, um galho seco de jabuticabeira.

Segundo plano ou plano da esquerda: elevado mais ou menos uns trinta ou quarenta centímetros acima do piso. Sala espaçosa, de uma antiga e tradicional fazenda de café. À esquerda-baixa, porta do quarto de Joaquim; à esquerda alta, porta em arco que liga a sala com a entrada principal da casa e as outras dependências. Na parede do fundo, à direita, porta do quarto de Marcelo; à esquerda, porta do quarto de Lucília. Bem no centro da parede do fundo, o mesmo relógio do primeiro plano. Na parede, entre a porta do quarto de Joaquim e a porta em arco, os mesmos quadros do primeiro plano. ${ }^{15}$

Como se observa em A Moratória, o dramaturgo prossegue com uma representação de espaço rural. Mesmo em desintegração, há uma ruralidade relembrada. A memória do dramaturgo, seus espaços passados vividos e agora teatralizados, organizam as rubricas da peça. Sobre essa capacidade, Georges Poulet lembra que:

Graças à memória, o tempo não está perdido, e, se não está perdido, também o espaço não está. Ao lado do tempo reencontrado está o espaço reencontrado. Ou, para 
ser mais preciso, está um espaço enfim encontrado, um espaço que se encontra e se descobre em razão do movimento desencadeado pela lembrança. ${ }^{16}$

Não bastando a referida indicação de espaço, de objetos e do tempo que eles representam, o dramaturgo também delimita o contexto em que transcorre o enredo:

Ação: No segundo plano ou plano da esquerda, a ação se passa em uma fazenda de café em 1929; no primeiro plano ou plano da direita, mais ou menos três anos depois, numa pequena cidade nas proximidades da mesma fazenda. ${ }^{17}$

0 texto teatral A Moratória é dividido em dois planos, portanto, duas unidades de espaço, tempo e ação. 0 início do texto se dá no plano urbano (1932), no qual se acompanha um primeiro diálogo de Lucília e Joaquim. Entre eles, nota-se uma certa insatisfação do pai ante o excesso de trabalho da filha numa máquina de costura.

Joaquim: (Pausa. Reaparecendo) - Não sei por que, depois que viemos para a cidade, você se afastou de tudo e de todos. ${ }^{18}$

Aqui já transparece, na fala de Joaquim, a unidade de espaço do presente texto teatral: Joaquim menciona o espaço urbano e deixa em aberto uma vida passada. Sutilmente, Jorge Andrade vai informando o leitor sobre a existência de uma certa insatisfação que ronda a consciência de Joaquim até que, então, a curiosidade do leitor/espectador acerca dos motivos do sofrimento do personagem é desvelada:

Joaquim: - Com a nulidade do processo, vou recuperar a fazenda. Darei a você tudo que desejar.

A fazenda é o espaço da concretude de Joaquim. Sua angústia provém da perda material da propriedade. Como conseqüência, o dramaturgo sugere a ocorrência de certo obscurecimento dos referenciais. Para o personagem, é incompreensível a perda de prestígio do rural perante as novas exigências da urbanização. Esse tema do rural em crise é trabalhado por Maria Isaura Pereira de Queiroz, para quem as respectivas origens não são um fenômeno novo, pois datam do começo do século XIX:

(...) Desenvolveu-se nessa época um gênero de vida citadino que a colônia não conhecera, com o aparecimento de uma vida burguesa urbana; na sociedade brasileira, o homem do meio rural perdeu pouco a pouco seu prestígio em relação ao 
citadino. Instalar-se na cidade passou a corresponder a uma promoção social, já por volta de meados do século XIX, entre os fazendeiros. ${ }^{19}$

Como se percebe, a representação de fazendeiro do século XX - Joaquim — não é nem um pouco tranqüila. Em Jorge Andrade, não há a idéia de cidade como "promoção social”, mas, ao contrário, a família de Joaquim é vista pela perspectiva da perda da propriedade, do espaço, dos referenciais de vida.

No decorrer do enredo, torna-se claro que Joaquim, como ex-fazendeiro que é, possui uma pendência judicial. Mas o que o dramaturgo ainda não anuncia são os respectivos motivos que levaram a tal processo, que, quando resolvido, permitirá à família de Joaquim recuperar a propriedade.

$\mathrm{Na}$ espera da solução de um problema que não está a seu alcance resolver, Joaquim inquieta-se com o presente. Um exemplo disso são as repreensões que faz à filha Lucília por se iludir com o trabalho em uma máquina de costura. $\mathrm{Na}$ tentativa de fazer com que ela tenha, como ele, mais esperanças, Joaquim narralhe uma interessante imagem de seus antepassados:

Joaquim: (Pausa) - Quando meus antepassados vieram para aqui, ainda não existia nada. Nem gente desta espécie.(Pausa) Era um sertão virgem! (Sorri) A única maneira de se ganhar dinheiro era fazer queijos. Imagine, Lucília, enchiam de queijos um carro de bois e iam vender na cidade mais próxima, a quase duzentos quilômetros! Na volta traziam sal, roupas, ferramentas, tudo que era preciso na fazenda. Foram eles que, mais tarde, cederam as terras para se fundar esta cidade. (Pausa) Quando eu penso que agora...

Impossível não recordar, nessa passagem, o personagem Francisco de $O \mathrm{Te}$ lescópio. Ao situar a tradição de Joaquim, o dramaturgo informa o leitor acerca da existência de um passado distante, no qual as relações eram permeadas por outros valores. Suas reminiscências atualizam um passado saudoso, que mais lembra uma "idade do ouro perdida", na qual o espaço familiar norteava as relações pessoais e inclusive as mercantis. Na evocação de Joaquim, um passado fundador é recuperado, a memória individual vai chamando as experiências esquecidas e desvelando os conflitos do presente em face das inúmeras mudanças, dentre elas: a passagem para a cidade e a fugacidade do tempo.

Tanto Francisco de $O$ Telescópio quanto Joaquim de A Moratória são homens do século XX. Nas suas rotinas rurais, eles são movidos pelo que E. Hobsbawm chama de "aquilo que se deve fazer", característica, segundo o historiador, muito presente nos ancestrais de homens e mulheres do presente século, pois, como contemporâneos, são muito mais movidos pelos conhecidos impul- 
sos externos a eles, dentre os quais podem-se mencionar: as necessidades econômicas, a tecnologia, o aparelho burocrático e as decisões políticas. ${ }^{20}$

Os personagens de Jorge Andrade representam, portanto, homens que caminham no limite dessas transformações. Trazem permanências de tempos que se transformam, mas convivem com a emergência de novos valores e novas formas de produção da vida.

Para Raymond Willians, a associação rural/urbano, seja como continuidade, seja como oposição, é uma recorrência no imaginário literário:

(...) Uma natural tranqüilidade campestre é contrastada com uma antinatural intranqüilidade urbana. 0 "mundo moderno", tanto em seu sofrimento quanto, de modo crucial, em seu protesto contra o sofrimento, é mediado pela referência a uma situação perdida que é melhor que ambos e que pode situar ambos: uma situação imaginada a partir de uma paisagem e de uma observação e uma memória seletivas. ${ }^{21}$

Ao relembrar os tempos idos, Joaquim discute com Lucília sobre os "favores” concedidos por Elvira — sua irmã — à família. É significativo o detalhe que marca esta passagem, pois nota-se que o homem, que no passado simbolizou a ostentação da produção cafeeira, no presente vive da solidariedade da irmã, pois recebe semanalmente um pouco de café. Assim, o espectador começa a ser sensibilizado com as dores de Joaquim: sua humilhação e dependência para com os parentes ilustram a fragilidade de alguém que já ostentou a riqueza do país.

Se Joaquim é saudoso, Lucília é cética com relação a seu cotidiano:

Lucília: (...) (Pausa) - O que sei é que preciso trabalhar se quisermos viver, pelo menos decentemente.

É a ação de Joaquim, ao olhar o quadro na parede, que anuncia para o espectador a existência de um outro plano de acontecimentos. Assim, o plano ru$\underline{\text { ral }}$ (1929) é revelado com a entrada de Helena — esposa de Joaquim — em cena.

0 ponto de partida do plano rural (1929) é um diálogo ríspido entre Helena e o marido. Nas suas falas, o leitor/espectador começa a ser informado acerca de uma possível crise financeira de Joaquim. As dificuldades são decorrentes da falta de chuva, mas, aos poucos, vai se percebendo que a situação do fazendeiro origina-se também de problemas financeiros adquiridos com o plantio e mercantilização do café. Em uma dessas passagens, Joaquim lamenta seu tempo: 
Joaquim: Não há mais café como antigamente.

Se o objetivo for procurar fundamento histórico e econômico para as perdas de Joaquim e seu grupo social, elas podem, de certo modo, ser justificadas com a crise na economia cafeeira, que tem seu auge por volta de 1929.

A perspectiva que Jorge Andrade escolhe para abordar tais acontecimentos é muito peculiar. É verdade que apresenta o fato "1930" não como marco de modernização para todos os grupos sociais. Mas as perdas que lamenta são também muito singulares. ${ }^{22}$

No prosseguimento da narrativa há a volta ao plano urbano (1932). É significativo perceber no texto os sutis mecanismos que Jorge Andrade vai utilizando para oscilar entre um plano e outro e, assim, construir duas histórias em tempos distintos, conseguindo, dessa forma, não confundir o espectador.

Ainda no plano urbano (1932), a ação de Lucília trabalhando numa máquina de costura vem demonstrar uma nova relação com o trabalho e realça sua positividade:

Lucília: Trabalho é para comprar o que for necessário. (..) Não se pode estragar o que já está estragado.

Em uma forte discussão entre Joaquim e Lucília aparece a situação afetiva da filha, pois Joaquim insiste em aconselhar o casamento com o advogado Olímpio. Assim, há toda uma revolta da moça diante do mandonismo do pai, pois, na atitude do velho, consta a histórica tentativa de unir a aristocracia decadente e 0 profissional liberal, típico representante de certo segmento social em ascensão. Revoltada com a intromissão do pai, Lucília insiste:

Lucília: A minha vida é esta. São duas coisas que não se misturam. Sou responsável também pela carga.

A continuação da cena acontece com o início de novo assunto, pois a entrada de Marcelo - filho de Joaquim - gera novos conflitos: sua forte personalidade, seu trabalho no frigorífico e sua inadaptação em virtude das novas exigências de uma vida urbana. Sobre a ociosidade em que vive pelas noites, Marcelo é repreendido pela mãe, ao que, então, responde alegando seu desconforto com a cidade:

Marcelo: Nada. Simplesmente conversando, dona Helena, de noite o ar é fresco, gostoso, me faz pensar! a senhora quer que eu venha me trancar neste quarto? Não tem pena de seu filho? 
Quando indagado sobre o trabalho, Marcelo oscila entre a insatisfação e a possível iminência da ascensão social e do consumismo. Na descrição do espaço de trabalho do personagem, acompanha-se a relação do homem com as máquinas. 0 frigorífico é lembrado por Jorge Andrade como uma referência ao mundo capitalista e as situações subumanas a que este sistema submete o homem. Conversando com Lucília, Helena lamenta a condição operária do filho e, por que não dizer, do tempo em que vive:

Helena: Para o homem é mais difícil enfrentar determinadas situações. Estão mais em contato com o mundo, têm mais necessidade do que nós de certas coisas! (...) Trabalhar no frigorífico, no meio de tantas máquinas! Antigamente o trabalho era tão simples! Agora é preciso fazer tudo com máquinas!

Através do receio de Helena, o dramaturgo lança suas preocupações com determinadas opções de que seu próprio país começava a lançar mão. Sobre essa histórica situação que, segundo Jorge Andrade, o Brasil vivencia a partir deste século, Hobsbawm lembra:

(...) As sociedades que se desenvolveram a partir da Revolução Industrial foram naturalmente obrigadas a inventar, instituir ou desenvolver novas redes de convenções e rotinas com uma freqüência maior do que antes. Na medida em que essas rotinas funcionam melhor quando transformadas em hábito, em procedimentos automáticos ou até mesmo em reflexos, elas necessitam ser imutáveis, o que pode afetar a outra exigência necessária da prática, a capacidade de lidar com situações imprevistas ou originais. ${ }^{23}$

Novamente há o retorno aos acontecimentos do plano rural (1929), tempo que continua a narrar, para o leitor, as crises domésticas da família de Joaquim. Aqui, o que se presencia, num primeiro momento, são as cobranças do pai em razão do imobilismo de Marcelo. 0 filho, ao ser cobrado pelo pai, lembra-lhe sua inadaptação também aos ofícios da fazenda. Mediante tal despreparo, Joaquim impõe algumas restrições, impedindo-o de continuar os estudos e delegandolhe tarefas na colheita do café. Mais uma vez, reclama:

Marcelo: Que posso fazer? Nunca trabalhei. (...) Não sei viver preso.

A continuação desta cena se dá com um diálogo entre Helena e Joaquim, no qual o leitor é informado sobre Lucília que, na ocasião, encontrava-se na cidade fazendo um curso de corte e costura. Num momento de intransigência, Joaquim ordena a Marcelo que diga à irmã que abandone o estudo e retorne à 
fazenda. Esta, para Marina Maluf, uma prática com relação à educação, muito corrente no referido meio social:

(...) os próprios pais se empenhavam mais naquilo que dizia respeito às atividades voltadas para a vida doméstica. Em vários relatórios, tanto de professoras quanto de inspetores, podem-se ler avaliações tais como "basta uma aluna saber algum trabalho de agulha para que os pais as tirem logo da escola" - ou "cada vez que as alunas vão adquirindo conhecimento os pais as tiram da escola". ${ }^{4}$

Helena, ao mencionar a relação da filha com um inimigo político de Joaquim, acaba por enfurecer mais ainda o marido que, por sua vez, de forma alguma aceita a relação da filha com um "qualquer", um desconhecido. Após muita insistência, Helena descreve o perfil social de Olímpio:

Helena: Voltou agora, formado. Já abriu escritório. É o melhor partido da cidade. Todas as mães de filhas...

Para Maria Isaura Pereira de Queiroz, a procura pela formação superior como uma das vias de ascensão social é um fato que remonta ao início do século 470 XIX. Seja no campo ou na cidade, o dinheiro e a instrução foram importantes determinadores das relações de poder. 0 personagem Olímpio, no século XX, é uma exemplar representação da capacidade de permanência dessa figura:

(...) 0 diploma universitário tornava-se para muitos a promessa suprema da ascensão social e a entrada nas universidades era bem mais procurada por causa desta esperança, do que com o fim de adquirir algum saber ou alguma eficiência. ${ }^{25}$

Mais uma vez, o dramaturgo utiliza-se do recurso de antecipar um plano no transcorrer do outro; isso acontece em meio a um curto diálogo entre Helena e Marcelo, este, prestes a sair para a cidade. Nessa nova antecipação, presenciase uma construção característica em Jorge Andrade, pode-se dizer que 'princípios de realidade' vão aos poucos adentrando a ficção. Fatos pertencentes à história do país são introduzidos no drama familiar de Joaquim. Ao ler um jornal, Joaquim menciona palavras como: 'ditadura' e 'PRP', o que imediatamente remete o leitor ao processo histórico pelo qual o país passou por volta de 1930, exatamente o momento de contextualização da unidade de tempo e ação da peça de Jorge Andrade.

Ao deixar o jornal, Joaquim volta-se para Lucília, quando então começam a falar de crises política e familiar, discussão que os leva a revelar, nos seus subtextos, as dificuldades que cada um sofreu em decorrência da crise cafeeira de 1930. As inúmeras perdas são verbalizadas: Joaquim, a fazenda; Lucília, o ma- 
trimônio. Nesse movimento, incluem-se Marcelo e Helena: o filho foi privado da liberdade anterior, já Helena não mais sente a tranqüilidade da estrutura familiar, calcada em valores construídos no âmbito da aristocracia rural.

Lucília: (Larga a costura) O Senhor pensa, papai, que gosto de saber que meu irmão viaja em jardineiras sujas, que trabalha num frigorífico no meio de pessoas que ele nunca viu e sem educação nenhuma? Pensa? Isso me atinge tanto quanto ao senhor. Acontece que precisamos encarar a situação de frente, não há outra saída.

Joaquim: Eu sei, minha filha. (...) Não pretendo dizer nada, mas não posso deixar de sentir. (...) Você vai à sala, assim? (...) É preciso guardar as aparências, Lucília. (...) Ainda somos o que fomos!

No trecho acima, fica claro esse desgosto com um tempo que, devido às mudanças provocadas, trouxe inúmeras perdas. Joaquim lamenta a condição operária do filho, pois não consegue deixar de sentir a "massificação" a que sua família foi submetida. Com essa opção, o dramaturgo reforça a insatisfação dos personagens quando nota o nivelamento social a que foi relegada a família do fazendeiro e, assim, seus valores são implicitamente colocados nas palavras de Joaquim. Dentre eles, a preocupação com as aparências, com a manutenção de certa pompa já perdida.

Para Marina Maluf, nem mesmo em momentos de profunda crise de produção e comercialização do café, as elites cafeeiras deixaram de preocupar-se com as aparências:

Cultivar a sociabilidade era um capítulo que fazia parte do conjunto de saberes a ser transmitido principalmente às filhas: fazer e receber visitas era um investimento que ao mesmo tempo reforçava antigos laços e criava novos (...). As elites pretendiam fazer as maneiras e o gosto parecerem parte essencial da natureza de seus membros, mas uma natureza cuidada, elaborada, "uma cultura tornada natureza”. (...). No espaço urbano, a identificação da condição social das camadas superiores podia ser feita na figura da mulher, que ostentava riqueza através de roupas, adereços, atitudes e gestos codificados pela moda. ${ }^{26}$

Ao fim do primeiro ato, Jorge Andrade utiliza-se do jogo da simultaneidade, pois a tristeza de Helena, graças ao endividamento de Joaquim e à conseqüente perda das terras, é apresentada, em seqüência, com a cena do plano ur$\underline{\text { bano }}$ - 1932 - , quando o leitor passa a acompanhar a alegria de Joaquim por saber, pelo jornal, que os devedores terão prazo de dez anos (moratória) para 
quitar suas dívidas, ou seja, a esperança de retorno à antiga propriedade tornase uma possibilidade.

Passado e presente tornam-se uma única temporalidade. Perdas e esperanças, tristezas e alegrias invadem o texto e os olhos do leitor. É perceptível, desse modo, que a escrita do texto obedece a uma lógica de movimento das experiências e da mente do autor transpostas para o texto.

0 início do segundo ato traz duas rubricas situando o leitor sobre o cenário e a disposição da cena. A ação no segundo plano ocorre algum tempo depois, e a do primeiro plano, na mesma semana.

Já na primeira cena do segundo ato, o dramaturgo expõe para o leitor/espectador a alegria de Joaquim com a possibilidade de voltar às suas terras por causa da moratória concedida aos devedores. Dessa forma, sua satisfação transparece nas sementes que compra para replantar o jardim. Sua lembrança das terras parece esboçada no olhar que lança ao galho de jabuticabeira dependurado na parede e na teimosia em não mais tomar remédios.

No diálogo com Lucília, percebe-se que a filha também acredita no possível retorno, exemplo disto é a máquina de costura, que começa 0 ato coberta com um pano. Esperançosa com o pai, ou pelo pai, o que se vê é a confiança de Lucília num retorno à vida passada. Na relação com a natureza, a evocação do passado:

Joaquim: Sementes para o jardim. Comprei bastante de girassol. (...) Em pouco tempo ficará bonito outra vez. Imagino como deve estar!

No decorrer do segundo ato — plano rural —, o leitor/espectador é informado acerca de um dinheiro que Joaquim não recebeu de um comerciante chamado Arlindo. Como conseqüência, surge pela primeira vez a iminência da perda das terras, fato que é lamentado com profunda mágoa por Helena:

Helena: Isso acontece com qualquer um, como está acontecendo. Não somos os únicos ameaçados. A maioria dos fazendeiros está na mesma situação. (...). Há homens que não sabem, não podem viver fora de seu meio. Seu pai sempre morou na fazenda. Para nós, mundo se resume nisto. Toda a nossa vida está aqui. (...) E não se esqueça, Lucília, que seu irmão não tem profissão, não estudou. Em que situação iríamos viver? (...) Viveríamos, mas não é só isto que importa. A gente nasce, vive e trabalha na terra. Não aprendemos a fazer outra coisa, nem a viver de outra maneira. Se tivéssemos que sair, não sei o que poderia acontecer.

Em A Moratória, há uma ruralidade sendo perdida. Os personagens, como a vegetação - o galho seco de jabuticabeira —, parecem desenraizar-se. A mo- 
bilidade e a indeterminação do espaço habitado muda também os referenciais de vida. Sobre essa ocupação dos espaços, Georges Poulet diz:

(...) a angústia vem com mais freqüência: a angústia em ver a mobilidade dos lugares acelerar ainda mais a mobilidade do nosso ser, já tão assustadora por si mesma. Pois, como não perder a fé na vida, quando se percebe que é ilusória a única fixidez em que se acreditava: a fixidez dos lugares, dos objetos ali situados? A mobilidade dos lugares rouba nosso último recurso. A que se agarrar, se os lugares, como os tempos e os seres, também são arrastados nessa corrida que só conduz até a morte? ${ }^{27}$

Ainda no plano rural (1929), é apresentado o personagem Olímpio, que chega à casa de Lucília para visitá-la e consolá-la da crise financeira da família. Num primeiro momento, percebe-se que esse consolo é apenas afetivo, pois Olímpio é pretendente de Lucília. Entre os dois, mais uma vez, o lamento das perdas:

Lucília: Tenho observado papai. Aquela calma não me engana. Há qualquer coisa atrás do seu silêncio que me assusta. Tenho visto papai andando pela fazenda como um animal acuado. Olha tudo demoradamente. Parece dizer adeus até às pedras, às árvores. Subitamente, parece que tudo adquiriu vida, sentido. 0 menor objeto, o movimento de um galho, os animais, as plantas, os gestos, tudo! Tudo passou a ter um significado diferente (...). Ontem encontrei papai no meio das jabuticabeiras, olhando-as, quase acariciando-as. Passava de uma para outra, examinando com ansiedade, como se todas estivessem doentes. Por um momento me deu a impressão de estar perdido, sem poder sair do meio delas. Fui ao seu encontro. Quando me viu, apressou o passo, fugiu de mim, como se eu fosse demais. (Pausa) Foi ele quem plantou todas!

Olímpio: Certos fatos são irremediáveis.

Torna-se difícil dissociar as falas de Olímpio do meio do qual ele é originário, o que permite desvelar as suas intenções como personagem. Olímpio aparenta ter consciência das verdadeiras causas da crise da família de Joaquim. Mas, ainda assim, no seu consolo a Lucília, diz haver sempre uma solução. A ambigüidade aqui se apresenta, pois o que se vê é a tentativa de Olímpio em salvar a união com Lucília, mas, ao mesmo tempo, suas falas deixam transparecer que não há nenhum outro caminho para a decadência dos fazendeiros. 0 posicionamento de Joaquim diante das circunstâncias fica claro na seguinte passagem:

Olímpio: (Pausa) Sei o que sente. Acha humilhante depender de mim, o filho do inimigo político de seu pai. Como se casamento fosse só isto: combinação de fortunas ou de partidos políticos. Nunca aprovei esta mentalidade e espero que isto 
acabe de uma vez. Sempre achei vergonhoso o que meu pai fez ao seu e o que o seu fez a muita gente. Esse coronelismo que não reconhece razão a ninguém, que destrói tudo, que é cego!

Se Olímpio é a representação do profissional liberal em ascensão, Joaquim não deixa de simbolizar uma variação do típico "coronel". 0 dramaturgo, em $A$ Moratória, localiza essas duas figuras, seus enfrentamentos e suas alianças em 1929. Para Maria Isaura Pereira de Queiroz, o coronelismo atinge sua plena expansão na Primeira República. Mesmo dentro dessa contextualização, 0 autor não estaria sendo ficcionalmente anacrônico, porquanto, segundo a pesquisadora, o desaparecimento do coronelismo não se apresenta de modo progressivo, mas sim, sensivelmente irregular.

Em Jorge Andrade, a política coronelista parece dar seus últimos suspiros, mas o dramaturgo não deixa de localizar as permanências, já que o personagem Olímpio é tecido como o sucessor das práticas de Joaquim. Mesmo habitando o espaço urbano, outras formas

de manutenção da riqueza e de poder são articuladas.

Na dialética rural/urbano, tanto o dramaturgo quanto Queiroz olham com cuidado esse momento de passagem, no qual a figura do "coronel" se defronta com a organização da vida na cidade:

Num primeiro momento, urbanização e crescimento demográfico são processos que concorrem para o desenvolvimento e a manutenção da estrutura coronelista, para, em seguida, pelo seu próprio incremento, levarem a esta abalos que tendem a arruiná-la. A cidade populosa, internamente muito diferenciada, vai escapando ao poder dos coronéis, tipo muito rudimentar de autoridade para servir a um conjunto complexo (...). 0 coronel, que fora o antigo "dono" da cidade, torna-se assim um dos elementos da estrutura de poder, ao lado de outros que ora agem como seus aliados, ora como seus opositores. ${ }^{28}$

A fragilização dos valores do meio social de Joaquim é aguçada a partir do momento em que ele encontra o filho Marcelo alcoolizado. 0 contraponto que vem da fala do personagem Olímpio é representativo do que será esse futuro para o segmento social ao qual a família de Joaquim pertence:

Olímpio: Não se preocupe (à Lucília) com o futuro. Para isto estarei junto de você. Venha! Vamos esperar seu pai. Ele vai compreender.

A relação rural/urbano aparece com toda a força no choque de gerações. A alegria de Joaquim em face da iminente volta para a fazenda se contradiz com a desilusão de Marcelo, o resultado disso é uma intensa cobrança e a lembrança 
de erros de ambas as partes. Na discussão, o pai cobra o desleixo do filho, e este, por sua vez, afirma estar despreparado para as novas exigências e, mediante isto, cobra o pai por não ter lhe ensinado a "ser operário".

Marcelo: (...) 0 senhor não compreende que depois de se ter vivido solto, no meio do campo; depois de se ter conhecido uma outra segurança, não é possível ficar preso o dia inteiro dentro de um salão com o chão sujo de sangue e receber ordens de gente que... que... Não agüentava aquilo. Estava farto. Era lá que a saudade, a consciência do que fomos, mais me oprimia.

Joaquim: Eu afirmo a você: (Num grito) ainda somos o que fomos!(...)

Nos personagens construídos por Jorge Andrade, o conceito liberal de trabalho não tem um valor positivo, ou seja, não é visto como o único caminho de ascensão social e realização humana. Ao contrário, o trabalho é sinônimo de sofrimento e aprisionamento, é sinal de proletarização e desqualificação do indivíduo. Isto é muito aparente e torna-se mais crítico quando o dramaturgo escolhe um frigorífico como espaço de trabalho de Marcelo.

Em meio a isso, há a figura da mãe, que se encarrega de apaziguar o conflito pai/filho, afirmando a Marcelo que aceite a dor do pai e que, assim, se conforme com o emprego para melhorarem de vida.

Ao saber das perdas das terras no plano rural, o dramaturgo parece construir uma única saída. É quando Olímpio se oferece não apenas como noivo de Lucília, mas também como advogado que irá acompanhar o processo, que irá pedir a nulidade judicial do confisco das terras de Joaquim. Mais uma vez aparece a insistência na idéia de a elite rural escorar-se em outro seguimento social. Em seguida, ocorre a chegada de Marcelo sem saber o que está acontecendo e, ao informar-se, não dá muita importância, talvez por não ter idéia das dificuldades do futuro.

Assim, o dramaturgo encaminha a finalização do segundo ato e, mais uma vez, cruza os dois planos para concluí-lo, e o leitor acompanha a seguinte trama: no plano urbano (1932) desenrolam-se os fatos que vão anunciar o cancelamento do processo de moratória; por outro lado, o plano rural (1929) acentua a humilhação de Joaquim, suas reações e de sua família com a iminente perda das terras e as conseqüências decorrentes deste processo:

Joaquim: Meus direitos sobre essas terras não dependem de dívidas. Nasci e fui criado aqui. Aqui nasceram meus filhos. Aqui viveram e morreram meus pais. Isto é mais do que uma simples propriedade. É meu sangue! Não podem me fazer isso!

A cena que encerra o segundo ato concentra-se no plano urbano; nela, Jor- 
ge Andrade mostra a chegada de Olímpio com a notícia de que a família de Joaquim não mais voltará para as terras, pois o ex-fazendeiro cometeu um engano ao acreditar que o governo concederia moratória de dez anos aos devedores. Segundo a alegação do juiz, a falha encontrada por Olímpio no processo judicial não procede.

No terceiro e último ato de A Moratória, o que se observa é a continuidade do plano urbano (1932), pois o plano rural (1929) transcorre algum tempo depois de sua localização no ato anterior. Assim, é destacado o retorno de Lucília à máquina de costura. Nesta atitude, o conformismo da filha com uma situação que, momentos atrás, como o pai, acreditou estar deixando.

No terceiro ato surge uma das mais belas e sensíveis cenas escritas por Jorge Andrade. Nela estão Helena e Joaquim na situação de despedida das terras. Mas, para construir o estado de solidão e abandono do casal, o dramaturgo recorre a vários momentos curtos e marcantes: a relação afetiva de Joaquim com a casa de fazenda, com as coisas que no dia a dia o cercam: balaústre, porta, forro do quarto, a plantação de café e o cheiro de terra molhada que entra pela noite com a chuva. Joaquim volta a recordar o hábito de sempre levantar cedo, o tempo em que namorou e depois se casou com Helena, o estilo de vida de seus ante-

476 passados, a vida na cidade e, enfim, o medo de deixar as terras. São elementos que vão expondo o apego às coisas e ao passado e, ao mesmo tempo, vão expondo a fragilidade de Joaquim. 0 dramaturgo vai minando, corroendo as certezas do personagem, elevando-o a um estado patético.

As formigas roendo as madeiras da casa - uma bela metáfora desse estado de passagem do tempo que Joaquim está sofrendo. É interessante perceber a relação de Joaquim com o relógio de parede; sendo um presente de seus antepassados, figura como um elemento central nas peças de Jorge Andrade.

Sobre os laços com seus antepassados, suas heranças e a relação com o tempo, que não perdoa a quem se esquece de notá-lo, Joaquim fala:

Joaquim: 0 pessoal de hoje é muito "perrengue". Só sabe ficar na cidade, fazendo o que não deve! (Pausa) Quero morrer como meu avô: caçando. (...) Meu avô comeu a matula e sentou-se encostado ao tronco de uma árvore. Quando os outros caçadores chegaram já estava morto. Um dos cachorros estava deitado em sua perna... e ele parecia dormir! (...) [o relógio]... foi presente de casamento de meu avô ao meu pai. Sabe? Meu avô tinha um propósito. Os antigos não davam nada assim sem mais nem menos. Sabiam sempre o que era mais útil. Junto com o presente veio a recomendação: "Meu filho! Não deixe nunca o sol pegar você na cama e saiba dividir o seu tempo, que tudo..." Disto ninguém poderá me acusar, Helena, em toda a minha vida, só aquela vez quando tive maleita não vi o sol nascer. 
Essa atmosfera provocada pelo personagem Joaquim é pensada por Raymond Willians - em caso semelhante - como sendo uma visão mítica de sensibilidade, na qual a natureza opõe-se aos avanços do mundo urbano industrializante, pois (...) as virtudes são encaradas como coisas claramente passadas, pertencentes a uma época anterior, perdida, da vida rural. Prosseguindo, Willians ainda lembra que tal leitura:

(...) vê a transição da sociedade rural para a industrial como uma espécie de decadência, como a causa e origem dos nossos problemas e convulsões sociais. Oculta a idéia de que não é o capitalismo que nos está prejudicando, e sim o sistema mais visível e mais facilmente isolável do industrialismo urbano. ${ }^{29}$

Na segunda cena deste último ato, o que se encontra é a insuportável sensação de Lucília ao ter que falar com sua tia sobre o seu vestido. Ajoelhada aos pés de Elvira, é visível a humilhação de ter que fazer a barra do vestido da tia e, ainda por cima, ouvi-la falar que não suporta mais ajudar "asilos". Nesta cena, 0 leitor/espectador fica sabendo das relações de Elvira com a família de Joaquim. Sabe-se, desta forma, que após a perda da fazenda ela sofre uma crise de consciência, passando a ajudar o velho "Quim", mas ainda assim fica relatando a Lucília, com desdém, os favores prestados.

Revoltada com as acusações da tia, Lucília comenta:

Lucília: Isso mostra bem o que a senhora é. A verdade é que deixou a nossa fazenda ir à praça e ser arrematada por gente que não tinha o menor amor às nossas terras.

Ao se despedirem da casa da fazenda, Joaquim consola Helena e, como lembrança, leva um galho de jabuticabeira. Em momento algum falam que estão deixando ou perdendo suas ligações com aquele espaço, mas procuram maquiar sua dor assumindo ser apenas uma viagem. De forma alguma aceitam ser uma viagem sem volta.

Mais uma vez, o dramaturgo antecipará a última cena para cruzá-la com a terceira; contrasta assim a despedida da casa rural com os fatos do plano urbano, quando Helena aguarda a chegada de Joaquim para anunciar-lhe a recusa da nulidade do processo judicial e que, tampouco, houve alguma moratória por parte do governo. Nesse sentido, o dramaturgo coloca em cena, simultaneamente, as perdas de Joaquim em distintos tempos: tanto em 1929 quanto em 1932. O que marca a vida de Joaquim é a "derrota" que o segmento social, do qual faz parte, sofre com o decorrer dos fatos.

No encerramento do texto, percebe-se uma certa apreensão por parte de Helena e Lucília, que, na dúvida, não sabem o que fazer e nem qual informação 
dar a Joaquim sobre a perda do processo. Acreditam até que a mentira seja a melhor verdade para o velho "Quim". A chegada do ex-fazendeiro é marcada pela angústia. Sentado e desfiando um trapo de pano, recolhe-se na sua dor. A reação de Lucília é surpreendente: no seu desespero, solidariza-se com a melancolia do pai, pois, como Joaquim, acreditou no retorno às terras.

Lucília e Olímpio saem "abraçados". Marcelo, sentado num canto, pouco interfere no triste e angustiante diálogo final entre Helena e Joaquim:

Joaquim: Abril! (Pausa) 0 café está sendo arruado! (As luzes vão abaixando lentamente)

Marcelo: Já não se houve o canto das cigarras!

Joaquim: 0 feijão da seca começa a soltar vagens!

Helena: Os que plantaram... vão começar a colher!

(As vozes se transformam num murmúrio e as luzes se apagam definitivamente).

Em A Moratória, a questão do espaço possui profunda importância. Há uma ambientação rural e urbana que, pela maneira como é tecida pelo dramaturgo e habitada pelos personagens, remete o leitor/espectador a pensar em tais

478 espacialidades pela perspectiva de uma lenta passagem. Nesse sentido, Jorge Andrade representa um segmento da sociedade brasileira em desenraizamento.

Essa escolha do dramaturgo justifica-se duplamente: num primeiro momento, é a atualização, para o texto teatral, de uma memória individual/coletiva. Esse exercício pode ser explicado:

(...) 0 sujeito que pode se auto reconhecer, através de lugares familiares que o situem, preserva seu ser, vale dizer, protege-se da sensação de isolamento, de anonimato, de abandono, construindo seu próprio aconchego. Assim, identidade seria, também, abrigo, portanto, proteção. ${ }^{30}$

Num segundo momento, A Moratória representa específica leitura acerca da passagem rural/urbano pós-1930, que o teatro brasileiro da década de 50 momento de escrita do texto - não se isentou de fazer.

Ao realizar esse texto e encená-lo em 1954, o dramaturgo demonstrou estar antenado com o debate sobre nacionalismo presente no contexto. Se a EAD e o TBC implementaram suas interpretações de homem brasileiro e de dramaturgia nacional, também o fizeram o Teatro de Arena e os intelectuais ligados ao ISEB (Instituto Superior de Estudos Brasileiros). Neste sentido, o estudo dessa pluralidade de representações, e práticas, permite entender a emergência de nacionalidades e não a preponderância de o "Nacional". 


\section{NOTAS}

${ }^{1} 0$ mais recente debate acerca da relação história/literatura/teatro pode ser encontrado nas seguintes referências: PATRIOTA, Rosangela. Vianinha: um dramaturgo no coração de seu tempo. São Paulo: Hucitec, 1999; PESAVENTO, Sandra Jatahy. "Contribuição da história e da literatura para a construção do cidadão: a abordagem da identidade nacional". Discurso Histórico e Narrativa Literária. Campinas: Ed. Unicamp, 1998, p. 10; PINTO, Júlio Pimentel. Uma Memória do Mundo. Ficção, memória e história em Jorge Luís Borges. São Paulo: Estação Liberdade, 1998.

${ }^{2}$ Natural de família tradicional e aristocrática do Oeste Paulista - Junqueira e Almeida Prado, Aluísio Jorge Andrade Franco (1922-1984) ingressou no meio teatral como aluno da EAD (Escola de Arte Dramática) em 1951, quando então escreveu seu primeiro texto teatral: $O$ Telescópio. 0 conjunto de suas principais peças está publicado na obra Marta, a Árvore e o Relógio, Ed. Perspectiva. A primeira peça de Jorge Andrade que recebeu encenação foi justamente A Moratória, que veio a estrear em 6 de maio de 1955 na inauguração do Teatro Maria Della Costa, de São Paulo. No elenco, figuravam os nomes de Fernanda Montenegro, Sergio Brito, Wanda Kosmos e outros; na cenografia e direção, o nome de Gianni Ratto.

${ }^{3}$ É discutível a idéia de que o TBC inaugura o profissionalismo no teatro brasileiro. As experiências de Pascoal Carlos Magno e do Teatro Universitário no Rio de Janeiro são exemplos dessas outras facetas do chamado "profissionalismo" de companhias no teatro brasileiro do século XX. Sobre isso, o pesquisador Armando Sérgio SILVA comenta que: “.. Pascoal Carlos Magno fundaria, em 1938, no Rio de Janeiro, o Teatro do Estudante, e Alfredo Mesquita, em 1942, o Grupo de Teatro Experimental em São Paulo. Décio de Almeida Prado, nos idos de 1943, formaria e dirigiria o Grupo Universitário de Teatro, também em São Paulo, e na mesma época, Luíza Barreto Leite seria uma das criadoras e atrizes do grupo Os Comediantes no Rio de Janeiro." In Uma Oficina de Atores - a Escola de Arte Dramática de Alfredo Mesquita. São Paulo: Edusp, 1989, p. 20.

${ }^{4}$ MESQUITA, Alfredo. "Depoimento". In Depoimentos II. Rio de Janeiro: SNT/MEC, 1977, p. 29. Grifo nosso.

${ }^{5}$ Idem, p. 24.

${ }^{6}$ GUZIK, Alberto. TBC: Crônica de um Sonho. São Paulo: Perspectiva, 1986, p. 56.

${ }^{7}$ ANDRADE, Jorge. “Teatro não é palanque”. Revista Isto é. São Paulo: 19/4/1978, p. 47.

${ }^{8}$ D’ARAÚJO, Maria Celina Soares. O Segundo Governo Vargas 1951-1954 - Democracia, Partidos e Crise Política. Rio de Janeiro: Zahar Ed., 1982, pp. 24-25.

${ }^{9}$ BETTI, Maria Ś́lvia. "Realismo americano e dramaturgia brasileira: pontos de contato". In Vintém - ensaios para um teatro dialético. São Paulo: Hucitec, n. 1, fev/mar/abr, 1988, p. 15.

${ }^{10}$ GUZIK, Alberto. Op. cit., p. 51. Grifo nosso. 
${ }^{11}$ SILVEIRA, Miroel. A Outra Crítica. São Paulo: Ed. Símbolo, 1976, p. 145. Grifo nosso.

${ }^{12}$ ANDRADE, Jorge. Revista Dionysos, dezembro de 1959, p. 65.

${ }^{13}$ HOLANDA, Sérgio Buarque de. Raízes do Brasil. 26-a ed. São Paulo: Cia. das Letras, 1995, p. 73.

${ }^{14}$ Idem, p. 92.

${ }^{15}$ ANDRADE, Jorge. A Moratória. Op. cit., p. 121.

${ }^{16}$ POULET, Georges. O Espaço Proustiano. Rio de Janeiro: Imago, 1992, pp. 54-55.

${ }^{17}$ Idem, p. 122.

${ }^{18}$ ANDRADE, Jorge. Op. cit. Todos os diálogos entre personagens, citados na seqüência, estão presentes na peça A Moratória, pp. 121-187.

${ }^{19}$ QUEIROZ, Maria Isaura Pereira de. “Classes Sociais no Brasil - 1950/1960”. In Cultura, Sociedade rural, sociedade urbana no Brasil. Rio de Janeiro: LTC/Edusp, 1978, p. 124.

${ }^{20}$ HOBSBAWN, E. A Invenção das Tradições. Rio de janeiro, Paz e Terra, 1984, p. 11.

${ }^{21}$ WILLIANS, Raymond. O Campo e a cidade na história e na literatura. São Paulo: Cia. das Letras, 1989, p. 247.

$480{ }^{22} 0$ tema Revolução de 1930 foi intensamente investigado pela historiografia brasileira; para quem queira iniciar a discussão é fundamental consultar: DE DECCA, Edgar. S. O Silêncio dos Vencidos. São Paulo: Brasiliense, 1981; FAUSTO, Boris. Revolução de 30: História e Historiografia. São Paulo: Brasiliense, 1982; (org.)

História Geral da Civilização Brasileira. 5a ed., São Paulo: Bertrand Brasil, tomo III, vol. III, 1991; FORJAZ, M.C.S. Tenentismo e Política: tenentismo e camadas médias urbanas na crise da Primeira República. Rio de Janeiro: Paz e Terra, 1977. SANTA ROSA, Virgínio. O Sentido do Tenentismo. $3^{\text {a }}$ ed., São Paulo: Alfa-Ômega, 1976. SODRÉ, Nelson W. Formação Histórica do Brasil. 9a ed., Rio de Janeiro: Civilização Brasileira, 1976. VESENTINI, C.A. \& DE DECCA, E.S. “A Revolução do vencedor". In Contraponto, 1, Rio de Janeiro, novembro de 1976. VESENTINI. C. A. A Teia do Fato. São Paulo: Hucitec, 1997.

${ }^{23}$ HOBSBAWN, E. Op. cit., p. 11.

${ }^{24}$ MALUF, Marina. Ruídos da Memória. São Paulo: Editora Siciliano, 1995, p. 217.

${ }^{25}$ QUEIROZ, Maria Isaura Pereira de. Op. cit., p. 126.

${ }^{26}$ MALUF, Marina. Op. cit., pp. 185-188.

${ }^{27}$ POULET, Georges. Op. cit., p. 18.

${ }^{28}$ QUEIROZ, Maria Izaura Pereira de. “O coronelismo numa interpretação sociológica”. In História Geral da Civilização Brasileira (Brasil República). Rio de Janeiro: Difel, vol. III, 1991, pp. 182-187.

${ }^{29}$ WILLIANS, Raymond. op. cit., pp. 103-137. 
${ }^{30}$ D’ALÉSSIO, Márcia Barbosa Mansor. “Intervenções da memória na historiografia: identidades, subjetividades, fragmentos, poderes”. Projeto História. São Paulo: Educ/Fapesp, nº 17, nov. 1998. pp. 269-280.

Artigo recebido em 03/2001. Aprovado em 10/2001. 